\title{
Effects of cohabitation with females on the sexual behavior of inexperienced male rats
}

\author{
MARGARET NEWELL AND DON PAGE, DEPARTMENT OF \\ PSYCHOLOGY, SIR GEORGE WILLIAM'S UNIVERSITY, \\ Montreal 25, Canada
}

Male hooded rats kept in a mixed colony for 12 days performed significantly better on a sexual rating scale than males limited to individual cells within sight and smell of estrous female rats. Prior to the experiment all males were housed under homosexual conditions. The colonial group's scores varied directly with the sexual specificity of the behavioral criterium measured.

Initiation of an experiment involved testing rats' sexual behavior in order to match two groups according to sexual drive levels. After numerous prolonged exposures to a variety of estrous females only 2 out of 24 rats exhibited any mounting ability. All showed excitement and interest by pursuit of females and avid licking of their genitals. But after approximately $15 \mathrm{~min}$ of this activity their interest would wane. An explanation was sought. If sex drive is unlearned and innate, sexually segregated rearing after weaning should have no effect (Barnett, 1963; Kagan \& Beach, 1953). Young and his colleagues (1961) observed that the sexual activity level, after castration and thereafter with administration of androgens, varies directly with the rats previous. sexual experience. This would imply learning is necessary. An experiment was devised to test if learning through experience derived through cohabitation with female rats had any effect on the sexual behavior of mature male rats.

Subjects

The Ss were 16 four month old male hooded rats weighing from $305 \mathrm{~g}$ to $353 \mathrm{~g}$ divided into two groups of eight each. They had all been reared in sexual isolation after weaning according to the practices of the Quebec Breeding Farm.

\section{Apparatus}

One $24 \times 24 \times 9$ in. wire cage composed of various compartments with openings between them, a second similarily sized wire cage with eight individual cells $9 \times 6 \times 9$ in. surrounding a central cell $24 \times 6 \times 9$ in. and a playbox $36 \times 24 \times 5$ in. was used for exercise and testing.

\section{Procedure}

The experimental group (Group E) was housed in the cage with openings along with 10 estrous female rats. The females were checked for plugs and receptivity to males daily, and replaced by receptive ones as required. The control group (Group C) males

Table 1

Scores and Chi Square Results

\begin{tabular}{|c|c|c|c|c|c|c|}
\hline \multirow[b]{2}{*}{ Item } & \multicolumn{6}{|c|}{ Behavioral Criteria } \\
\hline & Groomings & Lickings & Pursuits & Mounts & $\begin{array}{l}\text { Intro- } \\
\text { missions }\end{array}$ & $\begin{array}{l}\text { Ejacul- } \\
\text { ations }\end{array}$ \\
\hline
\end{tabular}

\begin{tabular}{lcccccc}
\multicolumn{7}{c}{ Group E } \\
Range & $0-4$ & $6-24$ & $0-3$ & $0-5$ & $0-21$ & $0-1$ \\
Mean & 1.38 & 14.75 & 1.125 & 1.63 & 6.25 & .25 \\
\hline \multicolumn{7}{c}{ Group C } \\
Range & $0-8$ & $8-22$ & $0-1$ & $0-2$ & $0-2$ & $0-0$ \\
Mean & 2.5 & 14.13 & .125 & .5 & .25 & 0 \\
\hline
\end{tabular}

Results

\begin{tabular}{llllllll}
$\begin{array}{l}\text { Chi square } \\
\text { Test }\end{array}$ & $4.57^{*}$ & .0 & $18.29 * *$ & $4.8^{*}$ & $18.29 * *$ & .5 \\
\hline
\end{tabular}

\begin{tabular}{lllllll} 
Test & $4.57^{*}$ & .0 & $18.29 * *$ & $4.8^{*}$ & $18.29 * *$ & .5 \\
\hline$* p<.05$ \\
$* * p<.001$
\end{tabular}

were limited to individual cells within sight and smell of their neighbors: estrous female rats in the large central cell and adjacent nules.

All the rats were exercised daily in the playbox for $15 \mathrm{~min}$ in groups of four to accustom them to the testing area and to handling. After 12 days the Ss were tested, two at a time, in the playbox with six estrous females. The test consisted of observing and recording the number of times each of the following acts were performed within a period of $15 \mathrm{~min}$; grooming (nuzzling, preening, sniffing and crawling over and around the female), licking and persistant sniffing of the anogenital area of the female, pursuit (receptive females stimulated by male licking retreat a short distance and assume a characteristic pose; the male then pursues them), mounting, intromission and ejaculation. Every intromission and ejaculation was timed with a stop watch.

Results

Group E scored significantly higher than Group $C$ on pursuits $p<.001$, mounting $.05>p>.02$ and intromissions $p<.001$ using chi square test for comparing observed frequencies with a specified theoretical distribution. The means and range of the raw scores obtained during the experiment and the results of the chi square tests are shown on Table 1.

The results for licking were very high and almost identical for both groups. Only in grooming did Group $\mathrm{C}$ exceed Group $\mathrm{E}$.

The two ejaculations for Group $E$ were not enough to show a significant difference.

Although both $\mathrm{E}$ and $\mathrm{C}$ males started the periods with vigorous female genital licking, Group E males became more sexually active and agressive whereas Group $\mathrm{C}$ males lost interest in the females. The five Group E Ss achieved their intromissions within $9 \mathrm{~min}$ $(540 \mathrm{sec})$ the one Group C S took $11 \mathrm{~min}(675 \mathrm{sec})$

Discussion

That the experimental animals had more intromissions and more ejaculations, generally higher sexual drive and ability than the controlled, suggest they gained experience or learned sexual behavior while living with females. This relates to Young's (1961) statement that experience interacts with hormone levels. He found that with castration and subsequent replacement therapy the regressive effects on sexual activity after the gonadectomy and resumption after androgen therapy were least pronounced in males with a regular and satisfying sexual history.

The results agree also with a series of studies reported by Young (1961) that rats reared homosexually or in isolation, thus deprived of learning opportunity, are less active sexually than those from a heterosexual environment. They are in direct opposition to the report that social contact is unimportant since isolated animals perform better than those from homo or heterosexual groups (Kagan \& Beach, 1953).

The latency of intromission was longer than indicated by most literature (Beach, 1956) and the number of intromissions required before ejaculations was very high. This would indicate that further work would be useful in assessing the average time normally required by male rats to complete one insemination pattern sequence.

\section{REFERENCES}

BARnETT, S. A. The rat a study in behavior. Chicago: Aldine Pub. Co. 1963.

BEACH, F. A. Characteristics of masculine sex drive. In Marshall R. Jones (Ed.), Nebraska symposium on motivation. Lincoln: University of Nebraska Press, 1956.

DAVIDSON, J. M. Characteristics of sex behavior in male rats following castration. Anim. Behav., 1966, 14, 266-272.

KAGAN, J., \& BEACH, F. Effects of early experience on mating behavior in male rats. J. comp. physiol Psychol, 1953, 46, 204-208.

YOUNG, W. C. (Ed.), Sex and internal secretions Vol. I (3rd ed.) Baltimore: Waverly Press Inc., 1961. 